\title{
Ulvan, a Sulfated Polysaccharide from Green Algae, Activates Plant Immunity through the Jasmonic Acid Signaling Pathway
}

\author{
Valérie Jaulneau, ${ }^{1,2,3}$ Claude Lafitte, ${ }^{1,2}$ Christophe Jacquet, ${ }^{1,2}$ Sylvie Fournier, ${ }^{1,2}$ \\ Sylvie Salamagne, ${ }^{3}$ Xavier Briand, ${ }^{3}$ Marie-Thérèse Esquerré-Tugayé, ${ }^{1,2}$ \\ and Bernard Dumas, ${ }^{1,2}$ \\ ${ }^{1}$ Laboratoire des Surfaces Cellulaires et Signalisation chez les Végétaux, Université de Toulouse, UPS, 24 chemin de Borde Rouge, \\ BP42617, Auzeville 31326 Castanet-Tolosan, France \\ ${ }^{2}$ Laboratoire des Surfaces Cellulaires et Signalisation chez les Végétaux, CNRS-Université Paul Sabatier, 24 chemin de Borde Rouge, \\ BP42617, Auzeville, 31326 Castanet-Tolosan, France \\ ${ }^{3}$ Groupe Roullier, Zone Industrielle, BP 72, 22260, Pontrieux, France
}

Correspondence should be addressed to Bernard Dumas, dumas@scsv.ups-tlse.fr

Received 12 November 2009; Accepted 8 February 2010

Academic Editor: Prem L. Bhalla

Copyright ( $\odot 2010$ Valérie Jaulneau et al. This is an open access article distributed under the Creative Commons Attribution License, which permits unrestricted use, distribution, and reproduction in any medium, provided the original work is properly cited.

\begin{abstract}
The industrial use of elicitors as alternative tools for disease control needs the identification of abundant sources of them. We report on an elicitor obtained from the green algae Ulva spp. A fraction containing most exclusively the sulfated polysaccharide known as ulvan-induced expression of a GUS gene placed under the control of a lipoxygenase gene promoter. Gene expression profiling was performed upon ulvan treatments on Medicago truncatula and compared to phytohormone effects. Ulvan induced a gene expression signature similar to that observed upon methyl jasmonate treatment (MeJA). Involvement of jasmonic acid (JA) in ulvan response was confirmed by detecting induction of protease inhibitory activity and by hormonal profiling of JA, salicylic acid (SA) and abscisic acid (ABA). Ulvan activity on the hormonal pathway was further consolidated by using Arabidopsis hormonal mutants. Altogether, our results demonstrate that green algae are a potential reservoir of ulvan elicitor which acts through the JA pathway.
\end{abstract}

\section{Introduction}

Plants have sophisticated mechanisms to perceive and defend against microbial pathogens. It is now widely accepted that early recognition of pathogens mainly relies on the detection of microbial (or pathogen) associated molecular patterns (MAMPs or PAMPs), formerly called elicitors. MAMPs are characteristic structures shared by large groups of microbes [1]. They are generally present in molecules that play a critical role in the lifestyle of the corresponding organism. A large diversity of molecules harboring MAMPs has been identified including proteins, polysaccharides, and lipids, and a few receptors able to specifically recognize MAMPs were also identified [2]. MAMP perception induces early events such as membrane depolarization, changes in intracellular calcium concentration [3], production of active oxygen species, phosphorylation cascades by mitogenactivated protein kinase [4], and activation of signaling pathways depending on the phytohormones, jasmonic acid (JA), ethylene, and salicylic acid (SA). The importance of these molecules as primary signals in the regulation of the plant immune response is well established. More recently, auxins, gibberellins, cytokinins, and abscisic acid (ABA), hormones implicated on plant development and response to abiotic stresses, emerged as players during biotic stress as well, [5].

A major class of inducers of plant immunity consists of oligosaccharides such as $\beta-1,3-1,6$ glucans, and chitinderived oligomers, which can be released from oomycetal and fungal cell walls during the interaction with their host plant [6]. These compounds are not restricted to microorganisms since they are also produced by marine 
organisms, algae, and crustaceans, thereby providing an inexpensive source of biologically active molecules which can be potentially used as plant protectants. The $\beta-1,6-1,3$ glucan called laminarin, a storage polysaccharide from the brown algae Laminaria digitata, stimulates defense responses in a variety of plant species providing protection against pathogen attack $[7,8]$. Besides these well-known oligosaccharide patterns, other algal polysaccharides were further shown to induce plant defense responses. Most of them carry sulfate groups, notably fucan and carrageenans, two sulfated polysaccharides from brown and red algae, respectively $[9$, 10]. They behave as typical MAMPs inducing rapid changes in intracellular calcium concentration $[3,11]$, an oxidative burst $[8,9,12]$ and downstream defense responses such as induction of enzymes involved in the phenylpropanoid pathway and pathogenesis related proteins $[9,10,12,13]$. The structure and composition of algal oligosaccharides were shown to be crucial for their activities on signaling pathways regulating plant defense. For example, sulfated oligosaccharides obtained from fucan and carrageenans, but not laminarin, were shown to induce the salicylic acid signaling pathway $[9,10]$. The crucial role of sulfate groups was further demonstrated by chemical sulfatation of laminarin $[8,9]$ leading to a compound that became an inducer of the SA signaling pathway in tobacco and of associated resistance to the tobacco mosaic virus [13].

In a previous work, we reported on the elicitor activity of a green algal crude extract on the model legume Medicago truncatula [14]. Green algae belonging to the Ulva genus are common seaweeds that are abundantly found worldwide generally proliferating in eutrophicated coastal waters [15]. The algal extract consisted of water soluble components, whose biochemical analyses revealed the presence of typical polysaccharides found in green algae, known as ulvan, suggesting that this molecule can act as a plant defense elicitor. The main constituents of ulvan are sulfated rhamnose residues linked to uronic acids, resulting in a repeated disaccharide unit $\beta$-D-glucuronosyl-(1,4)- $\alpha$-L-rhamnose 3sulfate, called aldobiouronic acid [16]. The Ulva extract was shown to induce a large set of defense genes upon treatment of M. truncatula leaves and to protect the plant against infection by the pathogenic fungus Colletotrichum trifolii [14].

In the present work, we have characterized the elicitors present in the green algal extract of Ulva spp. and performed in depth analysis of their activity through cellular and molecular approaches.

\section{Materials and Methods}

2.1. Plant and Algal Material. Nicotiana tabacum $L$. P1lox::GUS plants (obtained by B. Verdaguer, UMR 5546, Toulouse, France) were grown on soil in a growth chamber (16 hours light at $25^{\circ} \mathrm{C}, 8$ hours dark at $22^{\circ} \mathrm{C}$ ). Seeds of Medicago truncatula line F83005.5 (provided by J. M. Prosperi, ENSAM, INRA Montpellier, France) were surfacesterilized for 5 minutes in sulphuric acid, rinsed several times with sterile water, and germinated on Petri dishes for $2 \mathrm{~d}$ at $20^{\circ} \mathrm{C}$ in the dark after 1 night at $4^{\circ} \mathrm{C}$. Seedlings were transferred to soil and cultivated in a growth chamber (16 hours light at $25^{\circ} \mathrm{C}, 8$ hours dark at $22^{\circ} \mathrm{C}$ ). Arabidopsis thaliana seeds of the ecotype Columbia (Col-0), jar1-1, $N a h G$, and aba3.1 mutants and the transgenic line PR1::GUS [17] were deposited on damp soil at $4^{\circ} \mathrm{C}$ during two days and transferred in a growth chamber $\left(9\right.$ hours light at $22^{\circ} \mathrm{C}$, 15 hours dark at $20^{\circ} \mathrm{C}$ ) for 4 weeks. Green algae Ulva spp., a mixture of several Ulva species (mostly U. armoricana), were harvested on the north Brittany coast (France) at Archipel de Brehat by Biotechmarine in August 2004, washed with fresh water, and immediately frozen.

2.2. Preparation of Ulva Extracts. $100 \mathrm{~g}$ of water-washed algae were grinded and were autoclaved for 2 hours at $90^{\circ} \mathrm{C}$ $(1.97 \mathrm{~atm})$ in 11 distilled water and the resulting extract was filtered through a nylon mesh ( $80 \mu \mathrm{m}$ porosity) on a sintered glass funnel (G2 porosity). The filtrate was lyophilized and designated as "crude extract". In this extract, the compounds of high molecular mass were precipitated with 2.5 volumes of ethanol for 48 hours at $-20^{\circ} \mathrm{C}$. The supernatant and pellet were separated by filtration, lyophilized, and subsequently called "ethanol-soluble" and "ethanol-insoluble" fractions, respectively. Size exclusion chromatography of the ethanol-insoluble fraction was achieved on Sepharose CL 6 B column $(25 \times 26 \mathrm{~cm})$ using $100 \mathrm{mM}$ ammonium formiate as eluent. The column was calibrated with standard dextrans $(10-1500 \mathrm{kDa})$. The $600-400 \mathrm{kD}$ fractions were pooled and lyophilized. In a separate experience, $20 \mathrm{mg}$ of the ethanol-insoluble fraction were dissolved in $5 \mathrm{ml}$ of $100 \mathrm{mM}$ ammonium formiate, treated by ultrasounds ( $20 \mathrm{kHertz}, 5 \times 3$ minutes) and then submitted to size exclusion chromatography. The $60-40 \mathrm{kD}$ fractions were selected using the same conditions as above.

2.3. Biochemical Analyses of Ulva Spp. Extracts. Total uronic acid content was determined according to Blumenkrantz and Asboe-Hansen [18] using glucuronic acid as a standard. Neutral sugars were released by hydrolysis in $2 \mathrm{M}$ TFA $\left(120^{\circ} \mathrm{C}, 1\right.$ hour $)$. TFA was eliminated by evaporation. Sugars were analyzed by HPAEC-PA on anion exchange column (Dionex, CarboPac MA1) with suitable standards. Sulphur measurements were done using inductively coupled plasma atomic emission spectroscopy (ICP-AES).

2.4. Infiltration Assays and Plant Treatments. Fully expanded leaves of 5-week-old $N$. tabacum were infiltrated with water and fractions from the green algae $\left(1 \mathrm{mg} \cdot \mathrm{ml}^{-1}\right)$. Infiltrated tissues from at least 5 plants per treatment were collected 3 days after treatment. In the case of PR1::GUS transgenic Arabidopsis plants, fully expanded leaves of 4week-old plants were infiltrated with water, the ethanolinsoluble fraction $\left(1 \mathrm{mg} \cdot \mathrm{ml}^{-1}\right)$ and P2 $\left(500 \mu \mathrm{g} \cdot \mathrm{ml}^{-1}\right)$, a Phytophthora parasitica elicitor cell wall extract [19]. Fourweek-old $M$. truncatula and A. thaliana plants were treated with sterile water, Actilandes (Samabiol, France) at 0.01\%, MeJA $(500 \mu \mathrm{M})$ dissolved in Actilandes $(0.01 \%)$, ethanolinsoluble ulvan extract $\left(1 \mathrm{mg} \cdot \mathrm{ml}^{-1}\right)$ dissolved in Actilandes 
$(0.01 \%)$, and the salicylic acid analog acibenzolar-S-methyl (BTH, $40 \mu \mathrm{g} \cdot \mathrm{m}^{-1}$ ). Solutions were sprayed onto plant leaves ( $2 \mathrm{ml}$ per plant). For M. truncatula, a time course experiment was carried out at 1,2, and 6 days and leaves from 9 plants per time point were collected. In the case of $A$. thaliana, leaves from 3 plants were sampled at 5 days.

2.5. GUS Activity Assays. Proteins were extracted from infiltrated tissues of tobacco or Arabidopsis leaves. Glucuronidase activity was measured on the protein extracts using a fluorometric assay [20]. Briefly, $100 \mathrm{mg}$ of grinded tissues were lysed in $100 \mu \mathrm{l}$ of GUS buffer $(100 \mathrm{mM}$ Phosphate buffer, $\mathrm{pH}$ 7.0, $10 \mathrm{mM}$ EDTA) with $0.1 \%$ TritonX-100 and $10 \mathrm{mM} \beta$-mercaptoethanol. The fluorogenic reactions were carried out in $1 \mathrm{mM}$ MUG (4-methylumbelliferyl glucuronide, Sigma) in GUS buffer with $25 \mu \mathrm{l}$ of protein extracts in a reaction volume of $200 \mu \mathrm{l}$. Fluorescence was measured every 5 minutes during 90 minutes, on an FL600 Microplate Fluorescence Reader (Bio-Tek Instruments) at $37^{\circ} \mathrm{C}$ with $360 \mathrm{~nm}$ excitation and $460 \mathrm{~nm}$ emission. The fluorimeter was calibrated with freshly prepared MU (4methylumbelliferone sodium salt, Sigma) standards in the same GUS buffer. Protein concentration was determined by the method of Bradford on 96 well plates. $200 \mu \mathrm{l}$ of Bradford reagent (Bio-Rad Laboratories) were added to $10 \mu \mathrm{l}$ of samples. After incubation (15 minutes, room temperature), absorbance was measured at $565 \mathrm{~nm}$ on an ASYS Expert 96 (Isogen) spectrometer. Standard curve was done with 1$20 \mu \mathrm{g}$ of BSA (Sigma). Glucuronidase activity was calculated from the linear part of the reaction (between 10 and 60 minutes) and expressed as nkatal $\mathrm{mg}^{-1}$ of protein.

2.6. RNA Extraction and Microarray Hybridization. Total RNA from grinded leaf tissues was extracted using TRIzol reagent (Invitrogen) and purified using Microcon-30 columns (Millipore). $5 \mu \mathrm{g}$ of total RNA were used to synthesize Cy3- and Cy5-labeled cDNA targets using a mixture of $3 \mu \mathrm{g}$ of double anchored oligo (dT) $15 \mathrm{VN}$ primers and $3 \mu \mathrm{g}$ of random primers with CyScribe First Strand cDNA labeling Kit (Amersham Biosciences). Labeled cDNA was purified using the ChipShot Membrane Clean Up System (Promega), and labeling efficiency was checked by measuring absorbance at 260, 550, and $650 \mathrm{~nm}$ with a Nanodrop (Thermo Scientific). Only labeled cDNA having a frequency of incorporation of at least 20 labeled nucleotides per thousand was used for hybridization. Microarray analyses were performed using Mt16kOLI1Plus chips represented all 16086 tentative consensus sequences of the TIGR $M$. truncatula Gene Index 5 plus a set of 384 oligonucleotides representing transcription factors and regulators. Automatic hybridization of a mix containing the same quantity of Cy3and Cy5-labeled cDNA was performed in a Ventana Medical Systems room (Discovery) following the standard procedure. After 16 hours of hybridization at $42^{\circ} \mathrm{C}$, microarrays slides were washed twice in RiboWash reagent $\left(1\right.$ minute, $\left.20^{\circ} \mathrm{C}\right)$ and once in $0.1 \times \operatorname{SSC}\left(1\right.$ minutes, $\left.20^{\circ} \mathrm{C}\right)$. Slides were dried by centrifugation $\left(185 \mathrm{~g}, 5\right.$ minutes, $\left.20^{\circ} \mathrm{C}\right)$ and scanned using the Genepix 4000 scanner (Axon Instruments). Image processing was performed using the Mapix (Innopsys, France) software. Subsequently, the mean intensities of signal pixels and the mean intensities of background pixels were calculated for each spot in both channels. Spots were flagged "empty" in the case of $R<0.7$ for both channels. $R$ is defined as the difference between the mean intensity of signal pixels and the mean intensity of local background pixels divided by the standard deviation of local background pixels. A saturated loop design was done for the two time points. Cy3 and Cy5 data were treated separately as one channel array. Normalization was done by local linear regression analysis (LOWESS) using the limma library of $R$ software. All data were deposited in MIAME compliant format in the ArrayExpress database under the accession number EMEXP-1995.

2.7. Hormonal Profiling. SA, JA and ABA and their internal standards ${ }^{2} \mathrm{H}_{4}-\mathrm{SA},{ }^{2} \mathrm{H}_{5}$-JA were extracted and measured in M. truncatula leaf tissues according to a protocol adapted from Forcat et al. [21]. Hormones were extracted from $100 \mathrm{mg}$ frozen material, to which $40 \mathrm{ng}$ of internal standards were added at the beginning of extraction. Briefly, two successive extractions with $400 \mu \mathrm{l}$ of $10 \%$ methanol containing $1 \%$ acetic acid were done on ice as described preciously. $5 \mu \mathrm{l}$ of the supernatant were then analyzed by UPLC-ESIMS/MS using an Acquity UPLC coupled to a Micromass Q-Tof Premier (Waters, Massachusetts, USA) orthogonal acceleration time-of-flight (oa-TOF) mass spectrometer. Chromatographic separations were performed on a $100 \mathrm{~mm}$ $\times 2.1 \mathrm{~mm} \times 1.7 \mu \mathrm{M}$ Acquity UPLC BEH C18 analytical column (Waters, Massachusetts, USA) maintained at $35^{\circ} \mathrm{C}$. Temperature of the sample organizer was set at $4^{\circ} \mathrm{C}$. The binary solvent system included $\mathrm{A}=$ water $+0.1 \% \mathrm{HCOOH}$ and $\mathrm{B}=$ acetonitrile LC/MS grade. Gradient profile consisted of $0-1$ minute: $5 \% \mathrm{~B} ; 1-8$ minutes: $5-68 \% \mathrm{~B} ; 8-9$ minutes: 95\% B; 9-10 minutes: 95\% B; 10-11 minutes 5\% B, 11-12 minutes $5 \%$ B. Flow rate was $300 \mu \mathrm{l} /$ minutes and column eluent was directed to the mass spectrometer.

$\mathrm{SA}, \mathrm{JA}$, and ABA and their internal standards ${ }^{2} \mathrm{H}_{4}$ $\mathrm{SA},{ }^{2} \mathrm{H}_{5}$-JA were analysed as $[\mathrm{M}-\mathrm{H}]$-ions using electrospray ionization tandem mass spectrometry (ESI-MS/MS) in negative mode. The capillary voltage and cone voltage of mass spectrometer were set to $2.8 \mathrm{kV}$ and $30 \mathrm{~V}$, respectively. The source temperature was set to $120^{\circ} \mathrm{C}$ and the desolvation temperature to $400^{\circ} \mathrm{C}$. Nitrogen was used as both cone gas (301/hour) and desolvation gas ( $800 \mathrm{l} / \mathrm{hour})$. Argon was used as collision gas. For accurate mass measurement, the mass spectrometer was calibrated with sodium formate solution. To ensure accuracy and reproducibility, analyses were acquired using the leucine-enkephalin in real-time as the lock mass at a concentration of $500 \mathrm{pg} / \mu \mathrm{l}$ and flow rate of $2 \mu \mathrm{l} /$ minutes. Data were acquired in centroid mode by MassLynx software. The data acquisition rate was set to $0.25 \mathrm{~s}$, with a 0.02 -second interscan and the lockspray frequency was set to $10 \mathrm{~s}$ and data averaging over 3 scans. Quantification was based on pseudo-MRM (Multiple Reaction Monitoring) after collision-induced dissociation. Collision energy was determined for each compound after infusion experiments 
with individual phytohormone at $2 \mathrm{ng} / \mathrm{ml}, 15 \mathrm{eV}$ for SA and ${ }^{2} \mathrm{H}_{4}$-SA, $12 \mathrm{eV}$ for $\mathrm{ABA}$, and $17 \mathrm{eV}$ for $\mathrm{JA}$, and ${ }^{2} \mathrm{H}_{5}-\mathrm{JA}$. The MRM transitions for quantification were: $137.0>93.0$ for SA, $141.0>97.0$ for ${ }^{2} \mathrm{H}_{4}$-SA, $263.1>153.1$ for ABA, $209.1>$ 59.0 for JA, and $214.1>62.0$ for ${ }^{2} \mathrm{H}_{5}$-JA. Quantitative results were calculated using QuanLynx software (Waters). To generate standard curves, $40 \mathrm{ng}$ of internal standard were added to standards of SA, JA, and ABA ( $0.5 \mathrm{ng}$ to $250 \mathrm{ng} / \mathrm{ml})$. Analyte standard curves were calculated using QuanLynx and the area of the daughter ion of the sample to the daughter ion of the internal standard was determined $\left(\mathrm{SA} /{ }^{2} \mathrm{H}_{4}-\mathrm{SA}\right.$; $\mathrm{JA} /{ }^{2} \mathrm{H}_{5}$-JA and $\mathrm{ABA} /{ }^{2} \mathrm{H}_{4}-\mathrm{SA}$ ). Concentration of the sample analyte was then determined in relation to the internal standard in three independent samples for each treatment or time.

2.8. Protease Inhibitor Activity. Extraction of protease inhibitor was carried out according to Kunitz [22]. $1.5 \mathrm{~g}$ of $M$. truncatula leaf tissues harvested 6 days after treatment were ground in liquid nitrogen. The fine powder was suspended in $4.5 \mathrm{ml}$ of $0.5 \mathrm{M}$ Tris- $\mathrm{HCl}, \mathrm{pH} 8.5$, containing $0.5 \%(\mathrm{w} / \mathrm{v})$ polyethylene glycol and $3 \%(\mathrm{w} / \mathrm{v})$ polyvinylpolypyrolidone and allowed to thaw under occasional shaking for about 1 hour in a cold room. The liquid was cleared by centrifugation ( 1 hour, $13000 \mathrm{~g}$ at $4^{\circ} \mathrm{C}$ ). The supernatant was subsequently heated at $65^{\circ} \mathrm{C}$ for 10 minutes and the precipitate was removed by centrifugation ( 5 minutes, $10000 \mathrm{~g}$ ). The extract obtained by this procedure was used for determination of protease inhibitor activity. $250 \mu \mathrm{l}$ of extracts were brought to a volume of $450 \mu \mathrm{l}$ with phosphate buffer, $\mathrm{pH} 6.8$ in test tubes containing small magnetic bars and placed in a waterbath at $30^{\circ} \mathrm{C}$ where they were constantly stirred. $50 \mu \mathrm{l}$ of a trypsin solution (TPCK Cooper Biomedicals; $1 \mathrm{~g} \cdot \mathrm{ml}^{-1}$ in $1 \mathrm{mM} \mathrm{HCI}$ ) were added to each test tube except in the controls. After 3 minutes at $30^{\circ} \mathrm{C}, 500 \mu \mathrm{l}$ of $1 \%(\mathrm{w}: \mathrm{v})$ casein "Hammarsten" (Merck, Darmstadt, Germany) were added and incubated at $37^{\circ} \mathrm{C}$ for 2 hours. After precipitation in $3 \%(\mathrm{w}: \mathrm{v})$ TCA for 30 minutes in ice and centrifugation, absorbance at $340 \mathrm{~nm}$ of supernatant was measured. Proteins were detected by the method of Lowry et al. [23]. The protease inhibitor activity was expressed as trypsin $(\mu \mathrm{g})$ inhibited by plant proteins ( $\mathrm{mg})$.

2.9. RT-Q-PCR. Total RNA was extracted from $100 \mathrm{mg}$ shock-frozen leaf tissues using the SV Total RNA Isolation System (Promega) and dissolved in $30 \mu \mathrm{l}$ of RNase free water. RNA quality was checked on agarose gel and possible DNA contamination was controlled by PCR. $2 \mu \mathrm{g}$ of total RNA were subjected to reverse transcription with SuperScriptTM III (Invitrogen) with Oligo dT primers. Real-time RT-QPCR was performed on an ABI Prims SDS 7900HT (Applied Biosystems). Each $10 \mu \mathrm{l}$ PCR reaction contained $2 \mu \mathrm{l}$ a $1: 50$ dilution of the synthesized cDNA, 5X qPCR Master Mix Plus for SyberGreen I (Eurogentec), and primers $(0.15 \mu \mathrm{M}$ each). The PCR program consisted in 5 minutes incubation at $95^{\circ} \mathrm{C}$ followed by 40 cycles of $15 \mathrm{~s}$ at $95^{\circ} \mathrm{C}, 30 \mathrm{~s}$ at $60^{\circ} \mathrm{C}$. Primers efficiency was evaluated by performing real-time PCR on serial dilution of a mix of all cDNAs. Data normalization was performed using the constitutive expressed gene encoding $\beta$-TUBULIN. The biological experiment was repeated 3 times. Gene-specific primers were designed with a calculated melting temperature of $60^{\circ} \mathrm{C} \pm 0.5^{\circ} \mathrm{C}$ and a unique amplification not longer than $300 \mathrm{bp}$. The following primer sequences were used: $\beta$-TUBULIN, At5g44340, forward, $5^{\prime}$ GAGGGAGCCATTGACAACATCTT-3', reverse, 5' -GCGAACAGTTCACAGCTATGTTCA-3', PR1, At2g14610, forward, 5'-GGAGCTACGCAGAACAACTAAGA-3', reverse, 5' -CCCACGAGGATCATAGTTGCAACTGA-3', PDF1.2, At5g44420, forward, 5' -TCATGGCTAAGTTTGCTTCC-3', reverse, $5^{\prime}$-AATACACACGATTTAGCACC-3'.

2.10. Statistical Analyses. We performed Student's $t$-test to determine probability that the two means, respectively associated to the control and tested populations, were equal. The statistical analyses were done using the $R$ software (http://www.r-project.org/), where the $t$-test function was available from the stats library. We considered the two means significantly different when the $P$-value associated was weaker than .05 .

\section{Results}

3.1. Characterization of Ulvan as an Active Fraction from Green Algae. Green algae Ulva spp., mostly Ulva armoricana, was treated with hot water to yield a crude extract containing mainly polysaccharides, which accounted for $60 \%$ of dried material. Ethanol precipitation allowed the separation of high, insoluble from low, soluble, molecular mass compounds. Size exclusion chromatography showed that the ethanol-insoluble compounds were mainly composed of two macromolecular populations (Figure 1(a)): a high molecular mass polysaccharide fraction (MW $600-400 \mathrm{kDa}$ ) and a low molecular population which was less defined. The 600$400 \mathrm{kDa}$ fraction was sonicated in order to reduce the mean molecular mass of the polysaccharides and the resulting compounds were further fractionated on a Sepharose column. A major fraction containing polysaccharide fragments with a mean molecular mass of $50 \mathrm{kDa}(60-40 \mathrm{kDa}$ fraction) was selected for further characterization.

Uronic acid, neutral sugar and sulphur contents were determined in the crude extract and in all subsequent fractions (Table 1). The ethanol-insoluble fraction which represented $44 \%$ of the total material recovered from the crude extract contained uronic acids, rhamnose and sulfate as major components, consistent with the main constituents of ulvan, a known sulfated polysaccharide present in Ulva spp. [16]. Low amounts of xylose, galactose, and glucose residues were also found. In contrast, the ethanol-soluble fraction, which accounted for $56 \%$ of the crude extract, contained low amounts of sulphur and neutral sugars, while mannitol appeared to be the major component of the fraction (data not shown). The uronic acid, rhamnose, and xylose contents of the $600-400 \mathrm{kDa}$ and $60-40 \mathrm{kDa}$ fractions were higher than those of the ethanol-insoluble fraction; however relative amount of each molecules was conserved between the three fractions. 


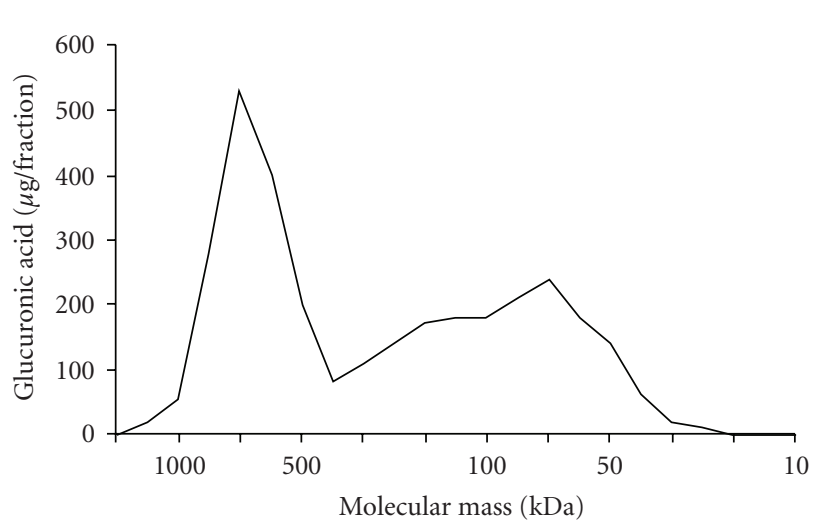

(a)

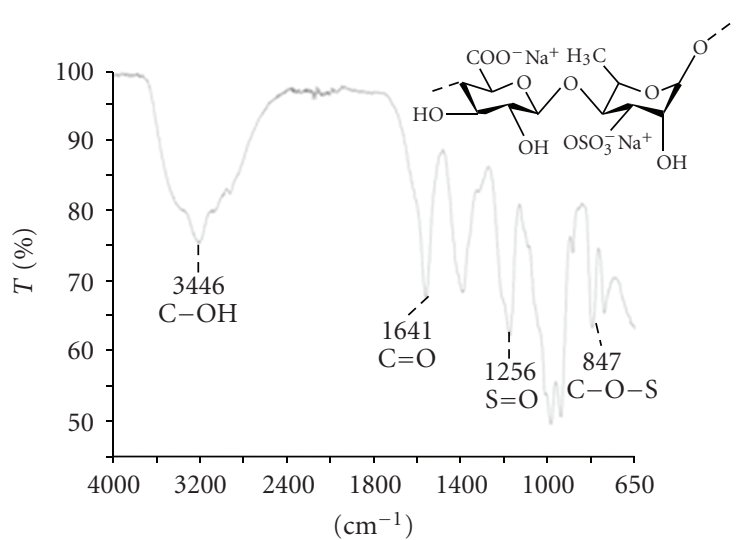

(b)

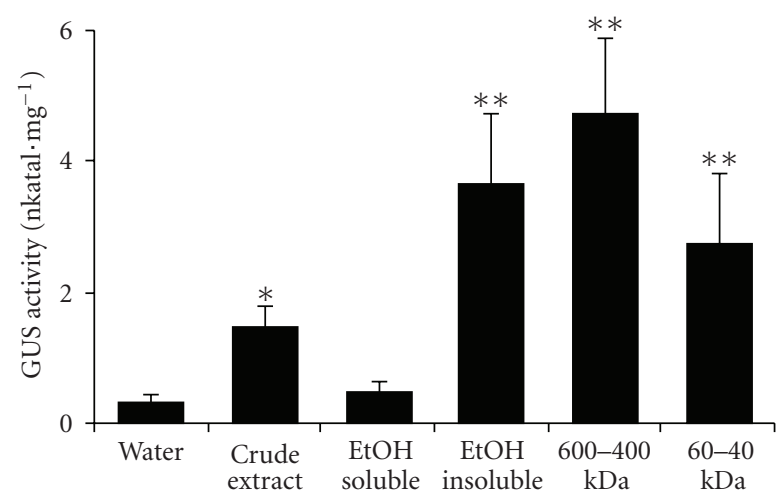

(c)

FIGURE 1: Biochemical analysis and biological activity of fractions from green algae Ulva spp. (a) Size exclusion chromatography of the high molecular mass compounds present in the ethanol-insoluble fraction recovered from the crude extract. Fractionation was followed by glucuronic measurement. (b) FITR spectra of the $600-400 \mathrm{kDa}$ fraction. The peaks at $847,1052,1256,1641$, and $3446 \mathrm{~cm}^{-1}$ are respectively generated by the bending vibration of $\mathrm{C}-\mathrm{O}-\mathrm{S}$ in axial position, the stretching vibration of $\mathrm{C}-\mathrm{O}, \mathrm{S}-\mathrm{O}, \mathrm{C}=\mathrm{O}$, and $\mathrm{C}-\mathrm{OH}$, all linkages being present in the constitutive dimer $\beta$-D-glucuronosyl-(1,4)- $\alpha$-L-rhamnose-3-sulfate. (c) Biological activity of the crude extract and fractions. GUS activity was measured on P1Lox::GUS transgenic tobacco 3 days after infiltration in leaves of the various samples $\left(1 \mathrm{mg} \cdot \mathrm{ml}^{-1}\right)$ as indicated. Means, for each treatment compared to the control mean using a Student's $t$-test. Treatment associated to a $P$-value $\leq .05$ or $\leq .01$ was marked, respectively, by ${ }^{*}$ or $* *$.

TABle 1: Chemical composition of an Ulva spp. crude extract and fractions obtained by ethanol precipitation and size-exclusion chromatography ( $\mathrm{mg} \cdot \mathrm{g}^{-1}$ of dry matter).

\begin{tabular}{|c|c|c|c|c|c|c|c|}
\hline \multirow{2}{*}{ Fraction } & \multirow{2}{*}{ Uronic acid } & \multicolumn{4}{|c|}{ Neutral sugars } & \multirow{2}{*}{$\begin{array}{l}\text { Uronic acid } \\
\text { Rhamnose }\end{array}$} & \multirow{2}{*}{ Sulphur } \\
\hline & & Rhamnose & Xylose & Galactose & Glucose & & \\
\hline crude & 59 & 78 & 8 & 6 & nd & 0.76 & 33.8 \\
\hline EtOH soluble & 0 & 2.5 & 0.1 & 1.6 & 0 & 0.00 & 13.8 \\
\hline EtOH Insoluble & 143 & 184 & 16 & 12 & 4 & 0.78 & 56.6 \\
\hline $600-400 \mathrm{kDa}$ & 245 & 345 & 24 & 11 & nd & 0.71 & 64.6 \\
\hline $60-40 \mathrm{kDa}$ & 215 & 325 & 25 & 18 & nd & 0.66 & 55.9 \\
\hline
\end{tabular}

nd. not determined

The Fourier Transform infrared (FTIR) analysis of all fractions, except the ethanol-soluble one, showed the typical absorption spectra of molecular linkages present in uronic acids and sulfated rhamnose. On the 600-400 kDa fraction FTIR spectra (Figure 1(b)), the peaks at 847, 1052, 1256, 1641 , and $3446 \mathrm{~cm}^{-1}$ are caused by the bending vibration of $\mathrm{C}-\mathrm{O}-\mathrm{S}$ in axial position, the stretching vibration of $\mathrm{C}-\mathrm{O}, \mathrm{S}=\mathrm{O}, \mathrm{C}=\mathrm{O}$ : and $\mathrm{C}-\mathrm{OH}$, respectively. Absorbance ratio between signals observed at $1256 \mathrm{~cm}^{-1}(\mathrm{~S}=\mathrm{O})$ and $1641 \mathrm{~cm}^{-1}(\mathrm{C}=\mathrm{O})$ were higher than 0.9 for the ethanolinsoluble and derived fractions (the $600-400 \mathrm{kDa}$ and the $60-40 \mathrm{kDa}$ fractions) while it was only 0.26 for the ethanolsoluble fraction (Table 2). The high values compared to the one for the crude extract suggested that the obtained fractions were highly enriched in a sulfated compound, ulvan. 
TABLE 2: Ratio of sulfate and carboxyl groups deduced from the FITR spectra of ulvan-containing fractions. Signals observed at 1256 and $1641 \mathrm{~cm}^{-1}$ are caused by the stretching vibration of the $\mathrm{S}=\mathrm{O}$ of sulfated rhamnose and of the $\mathrm{C}=\mathrm{O}$ of uronic acid, respectively.

\begin{tabular}{lc}
\hline Fraction & $\mathrm{S}=\mathrm{O}$ \\
& $\mathrm{C}=\mathrm{O}$ \\
\hline Crude & 0.68 \\
EtOH soluble & 0.26 \\
EtOH insoluble & 0.93 \\
$600-400 \mathrm{kDa}$ & 0.97 \\
$60-40 \mathrm{kDa}$ & 0.96 \\
\hline
\end{tabular}

To look for a potential elicitor activity, the various fractions were infiltrated into the leaves of transgenic tobacco plants expressing the uidA reporter gene (encoding the enzyme $\beta$-glucuronidase, GUS) fused to the $2.3 \mathrm{~kb}$ regulatory promoter region of the tobacco lipoxygenase gene NtLOX1 (Fanmartino et al. [24]). NtLOX1 is induced in response to elicitor and jasmonic acid treatment as well as during infection with an oomycete pathogen [25]. Infiltration of ethanol-insoluble, $600-400 \mathrm{kDa}$ and $60-40 \mathrm{kDa}$ fractions $\left(1 \mathrm{mg} \cdot \mathrm{ml}^{-1}\right)$ induced a strong GUS activity whereas no induction was observed with the ethanol-soluble fraction (Figure 1(c)). These results showed that the lipoxygenaseinducing activity is positively correlated with the presence of ulvan in the fractions.

\subsection{Ulvan Preparation Induces Transcriptome Changes Similar} to Those Induced by Methyl Jasmonate in the Model Legume Medicago truncatula. The legume $M$. truncatula was previously shown to be a useful model to study the elicitor activity of Ulva extract [14]. Thus we used this model plant to investigate transcriptomic changes in response to ulvan extracts (ethanol-insoluble fraction, $1 \mathrm{mg} \cdot \mathrm{ml}^{-1}$ ) and compare them to the variations observed upon treatment with two well-known mediators of plant defense, the salicylic acid analog acibenzolar-S-methyl (BTH, $40 \mu \mathrm{g} \cdot \mathrm{ml}^{-1}$ ) and methyl jasmonate (MeJA, $500 \mu \mathrm{M})$. Four-week old $M$. truncatula plants were treated by pulverisation on the aerial part. Total RNA samples prepared from the leaves 1 and 2 days after treatment and pooled. Other samples were collected 6 days after treatment. Two independent biological replicates were performed and two extractions of total RNA were performed for each pool of plants. Microarrays were performed on Mt16kOLI1Plus chips representing about 16,000 open reading frames of $M$. truncatula [26]. After ANOVA analysis, a gene was considered responsive to the treatments if it associated with a $P$-value $\leq .05$ and regarded as differentially expressed if the absolute value of $\log _{2}$ ratio was $\geq 0.584$ ( $>1.5$-fold induction or $<0.67$ repression).

Ulvan treatment induced 317 genes and repressed 146 genes among which the most induced ( $>2$-fold induction) and most repressed genes $(<0.5$-fold) are listed in Tables S1 and S2 in supplementary material available on line at doi: $10.1155 / 2010 / 525291$. More than $40 \%$ of the differentially expressed genes were found to be affected by MeJA whereas only $10 \%$ were common with BTH treatment (Figure $2(\mathrm{a})$ ). The genes coexpressed by Ulvan and MeJA are related to various functional classes (Supplementary Tables S3 and S4), notably some well-known jasmonic acid-responsive genes (Table 3 ) belonging to defense responses, including lipoxygenase, hydroxyproline rich glycoproteins, proline rich proteins, cysteine rich antifungal proteins (defensin) and wound induced protein [27]. Other genes also regulated by this pathway such as pectinesterase inhibitors, peroxidase, and GDSL lipase [28-30] were induced by ulvan.

Analysis of the microarray results suggested that ulvan treatment could also affect other hormone pathways which have been shown to interfere with defense reaction [5]. A GH3-auxin responsive gene (MT000633) was found highly induced upon ulvan treatment as well as a protein phosphatase type 2C (PP2C; MT011314) (Supplementary Table $\mathrm{S} 1$ ). It has been shown that PP2Cs acts in Arabidopsis as negative regulator of the ABA response. Two genes coding GRAS transcription factors were also induced by ulvan. GRAS factors are involved in various processes in plants including the response to gibberellins [31]. Interestingly, this family of transcriptional factors has been also involved in response to bacterial and fungal elicitors, providing evidence for a crosstalk between elicitor and gibberellin response [32, 33].

Among typical plant responses to JA is the induction of trypsin inhibitory activity [34]. Therefore, we measured the antiproteinase activity of $M$. truncatula leaves 6 days after plant treatment with ulvan extract $\left(1 \mathrm{mg} \cdot \mathrm{ml}^{-1}\right)$, MeJA $(500 \mu \mathrm{M})$, and BTH $\left(40 \mu \mathrm{g} \cdot \mathrm{ml}^{-1}\right)$. The trypsin inhibitory activity was found to be induced upon ulvan and MeJA whereas no effect of BTH treatment was observed (Figure 2(b)). This strongly reinforced the notion that ulvan acts through a jasmonic acid signaling pathway in M. truncatula.

Since the transcriptomic data indicated an effect of ulvan on the hormonal balance, the level of SA, JA, and ABA was measured by a method allowing the simultaneous detection of these compounds in a single extract (see Section 2). Whereas a slight decline of free SA contents was observed, ulvan induced a transient elevation of JA content (Figure 2(c)). In addition, a transient decrease of free ABA concentration was also observed.

3.3. The Elicitor Activity of Ulvan Depends on JAR1 in A. thaliana. The effect of ulvan on signaling and defense was additionally studied in A. thaliana by following the expression of PDF1.2, a JA responsive defensin gene, as well as PR1a and PR5, two SA responsive genes. Ulvan $\left(1 \mathrm{mg} \cdot \mathrm{ml}^{-1}\right)$ was sprayed onto the leaves of four-week oldplants and gene expression was measured 5 days later. As shown in Figure 3(a), PDF1.2 was highly induced in response to ulvan, an effect which was strongly reduced in the jasmonic acid resistant, jar1.1 and the abscisic acid deficient, aba3.1 mutants. In contrast, expression of the PR1a and PR5 genes, two $S A$ responsive genes, was not induced by ulvan and was slightly repressed in the case of the PRla gene. The same kind of experiment was done by using the salicylic acid-deficient NahG line. A more intense induction of PDF1.2 upon ulvan 


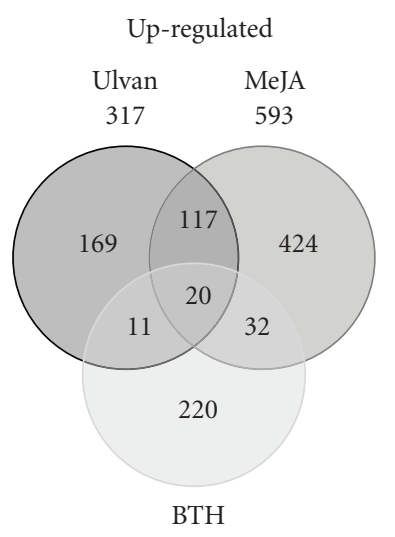

283

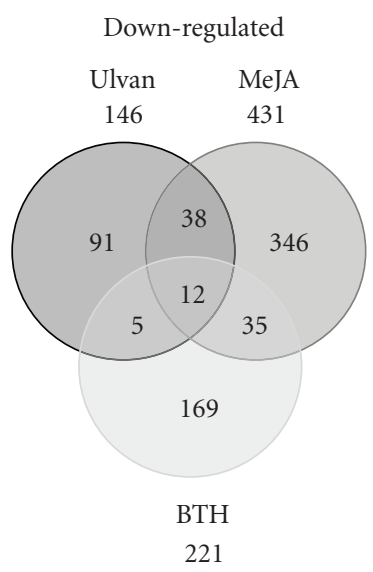

221

(a)

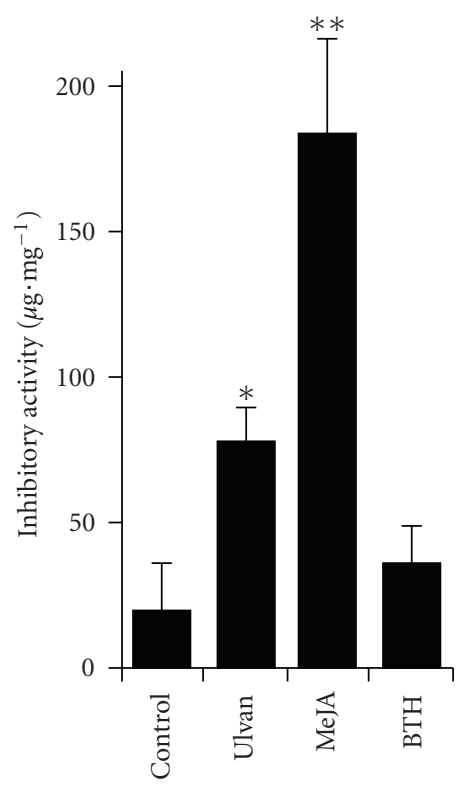

(b)

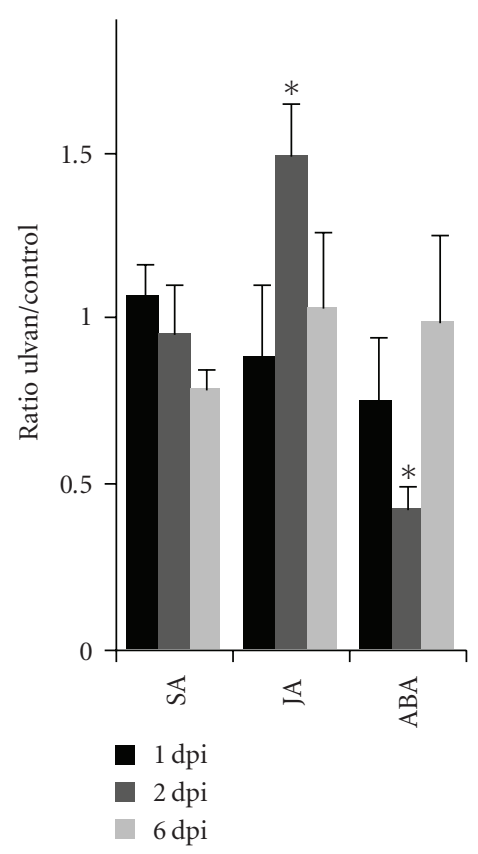

(c)

FIgURE 2: Comparison of $M$. truncatula transcriptomic responses to ulvan, BTH, and MeJA. M. truncatula plants were treated by ulvan (ethanol-insoluble fraction, $\left.1 \mathrm{mg} \cdot \mathrm{ml}^{-1}\right)$, MeJA $(500 \mu \mathrm{M})$, BTH $\left(40 \mu \mathrm{g} \cdot \mathrm{ml}^{-1}\right)$, or Actilandes $(0.01 \%)$ as the control. (a) Venn diagrams showing the total number of genes up-regulated (left) or down-regulated (right) upon ulvan, BTH, and MeJA treatments and their respective overlaps. Data obtained at $1-2$ and 6 days after treatment are mixed. Only genes with a $P$-value $\leq .05$ and a $\mid \log (2)$ ratio| $\geq 0.584$ were selected. (b) Trypsin protease inhibiting activity measured on M. truncatula leaves harvested 6 days after treatment. Activity is expressed as $\mu \mathrm{g}$ of trypsin inhibited per $\mathrm{mg}$ of protein extracted from the leaves. The average of measures done on three biological replicates is represented. (c) Measurement of the SA, JA, and ABA contents of M. truncatula leaves harvested 1, 2, and 6 days after treatment using UPLC-ESIMS/MS. Mean of the relative amount after ulvan treatment compared to Actilandes, used as control, was calculated from three experiments and represented on the graph. Mean for each treatment was compared to the control mean using a Student's $t$-test. Treatment associated to a $P$-value $\leq .05$ or $\leq .01$ was marked, respectively, by $*$ or $* *$.

treatment was found in the NahG line than in the wildtype. Accordingly, expression of the PR1a and PR5 genes was induced in the NahG line suggesting that these genes can be regulated by an SA-independent mechanism.

To confirm the absence of PR1a gene induction, leaves of a PR1a::GUS transgenic line [17] were infiltrated with ulvan or a Phytophthora parasitica elicitor (P2), known to induce the SA signaling pathway [10]. As shown in Figure 3(b), a strong induction was observed in the case of P2 infiltration, whereas a GUS activity similar to the control was obtained upon ulvan infiltration. We conclude from these experiments that ulvan affects defense in A. thaliana through the JA signaling pathway, which acts synergistically with the ABA pathway and is antagonized by the SA signaling pathways. 
TABLE 3: Defense genes upregulated after ulvan or MeJA treatments of M. truncatula.

\begin{tabular}{|c|c|c|c|c|c|c|}
\hline \multirow{2}{*}{ ID-Mt16kPlus } & \multirow{2}{*}{ TIGR Gene Index v8 } & \multirow{2}{*}{ Annotation } & \multicolumn{2}{|c|}{ Ratio } & \multicolumn{2}{|c|}{$P$-value } \\
\hline & & & Ulvan & $\mathrm{MeJA}$ & Ulvan & MeJA \\
\hline MT004351 & TC104560 & Phospholipase D & 1.72 & 1.66 & 0.036 & 0.046 \\
\hline MT014135 & BF640256 & Lipoxygenase & 1.51 & 1.50 & 0.011 & 0.011 \\
\hline MT015543 & TC107737 & Wound-induced protein & 1.54 & 1.57 & 0.038 & 0.031 \\
\hline MT006789 & TC104515 & Defensin & 2.31 & 1.85 & 0.001 & 0.006 \\
\hline MT008333 & TC95553 & HRGP-like & 2.08 & 2.01 & 0.032 & 0.039 \\
\hline MT007566 & TC100849 & Pectinesterase inhibitor & 1.80 & 1.51 & 0.003 & 0.022 \\
\hline MT000246 & ТC94445 & Trypsin protease inhibitor & 37.31 & 6.41 & 0.010 & 0.018 \\
\hline MT000087 & TC106371 & Protease inhibitor & 1.83 & 1.73 & 0.026 & 0.020 \\
\hline MT005382 & TC111698 & Phytochelatin synthetase-like protein & 1.55 & 1.75 & 0.015 & 0.003 \\
\hline MT014728 & TC131819 & Peroxidase & 1.68 & 1.67 & 0.030 & 0.025 \\
\hline MT002340 & TC96537 & Thioredoxin reductase & 1.75 & 1.74 & 0.035 & 0.038 \\
\hline MT004461 & TC95580 & Heat shock protein & 1.67 & 2.16 & 0.015 & 0.001 \\
\hline MT015962 & TC105992 & Lipase GDSL & 1.51 & 1.52 & 0.037 & 0.034 \\
\hline MT000987 & TC101355 & Anthranilate N-benzoyltransferase-like & 1.51 & 1.52 & 0.013 & 0.011 \\
\hline MT014991 & TC99521 & Tropinone reductase & 1.53 & 1.77 & 0.014 & 0.002 \\
\hline MT006133 & ТC98074 & 4-coumarate-CoA ligase & 1.71 & 1.85 & 0.001 & 0.000 \\
\hline
\end{tabular}

M. truncatula plants were sprayed with ulvan (ethanol-insoluble fraction at $\left.1 \mathrm{mg} \cdot \mathrm{mL}^{-1}\right)$ or MeJA $(500 \mu \mathrm{M}$ ) with Actilandes at $0.1 \%$. Leaves collected 1 and 2 days after treatment were pooled and other samples were collected after 6 days. The fold ratio is calculated with the corresponding Actilandes-treated sample.

\section{Discussion}

In a previous work, we reported on the elicitor effect of a crude Ulva spp. extract on plant defense [14]. The present study was undertaken in order to identify (i) the active molecules of the extract, (ii) the transcriptomic signature induced by ulvan treatment, and (iii) the plant signaling pathways involved in the response of the plants to ulvan.

From an algal crude extract, active molecules were fractionated according to their size, solubility, and activity. Active fractions were selected on the basis of their ability to induce, in transgenic tobacco, a reporter GUS gene construction under the control of the elicitor-inducible NtLOX1 gene promoter (Fanmartino et al. [24]). The major recovered active compound was identified as ulvan, a polysaccharide specifically found in green algae. Its molecular mass distribution, sugar composition, and infrared spectra were similar to previous data reported on purified ulvan. These include the molecular mass distribution into high (1200-300 kDa) and medium (180-85 kDa) molecular mass populations [35], the amounts of uronic acid and rhamnose, $36 \mathrm{~mol} \%$ and $55 \mathrm{~mol} \%$, respectively [36-38] and the typical absorption spectra of molecular linkages present on ulvan [39]. Ulvan is a complex branched polysaccharide composed of uronic acids (galacturonic acid, iduronic acid) and neutral sugars (rhamnose, galactose, xylose) which can be sulfated (rhamnose). Ulvan extracted from natural source may also contain divalent cations such as $\mathrm{Ca}^{2+}$. The high molecular weight fraction we used in our experiments contained mainly a polysaccharide with a monosaccharide composition typical of ulvan (rhamnose, uronic acid, and xylose, galactose) and sulfate. These components account for $65 \%$ of the fraction dry mass. However, this probably indicates a partial hydrolysis of the polymer since it has been shown that ulvan is partially resistant to TFA hydrolysis [38]. Finally, the FITR spectra done on the purified fraction indicates linkages typically found in ulvan. All these data strongly suggest that the fraction is, at least, highly enriched in ulvan and this preparation does not contain contaminants such as proteins or secondary metabolites. Interestingly, the mean molecular size of ulvan was reduced to about $50 \mathrm{kDa}$, corresponding to ulvan fragments of about 100 residues without modification of the biological activity.

The transcriptome of Medicago was largely affected by ulvan treatment and this analysis showed a strong similarity between MeJA and Ulvan responses. Accordingly, an increase of proteinase inhibitory activity, a typical MeJA responsive marker, was observed upon ulvan treatment. In addition, ulvan induces expression of JA-dependent genes like the PDF1.2 defensin in A. thaliana and the lipoxygenase NtLOX1 promoter in $N$. tabacum $[40,41]$. Importantly, induction of PDF1.2 in A. thaliana was dependent on JAR1, an essential gene in the JA signaling pathway. No induction of typical SA-dependent defense responses was observed upon ulvan treatment, such as SA accumulation in M. truncatula tissues or PR1a and PR5 expression in A. thaliana. Together, these results show that ulvan elicits a JA signaling pathway but not an SA-dependent pathway in plants belonging to three botanic families, Nicotianae tabacum (Solanaceae), Arabidopsis thaliana (Brassicaceae) and Medicago truncatula (Fabaceae). Fucan and carrageenans, two sulfated polysaccharides extracted from algae, were previously shown to induce lipoxygenase gene expression in tobacco $[9,10]$ suggesting that activation of JA pathway could be a general feature of sulfated oligosaccharides. The measure of SA, JA 


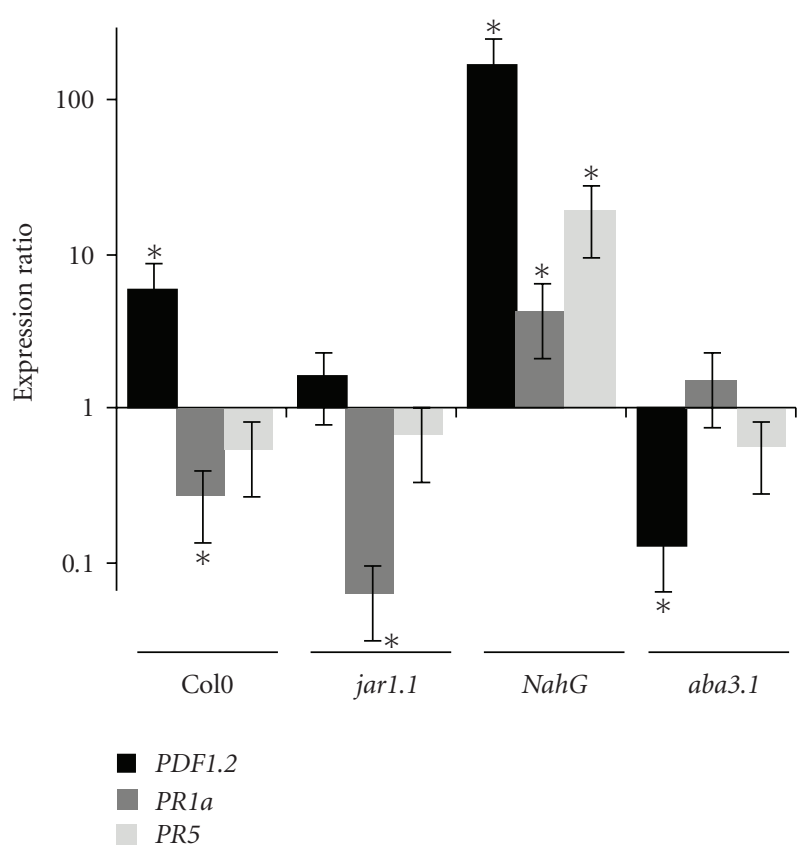

(a)

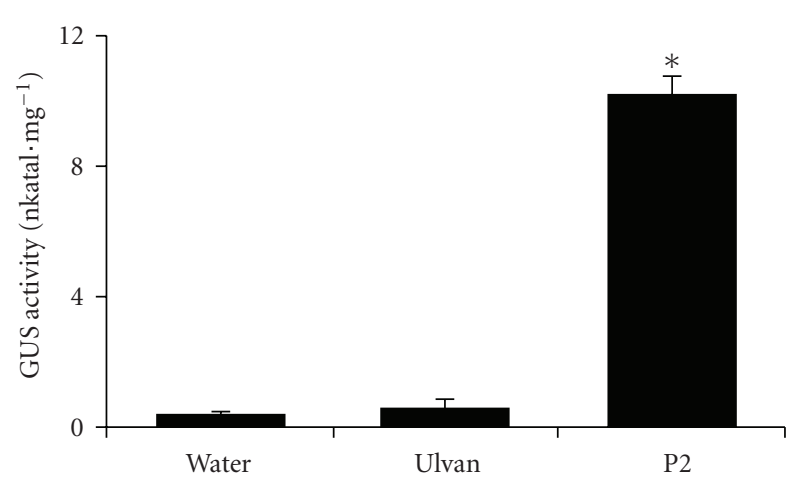

(b)

Figure 3: Expression of $A$. thaliana defense genes in response to ulvan. (a) RT-PCR analysis of PDF1.2, PR1a and PR5 expression in Col0, jar1.1, NahG and aba3.1 A. thaliana 5 days after ulvan treatment (ethanol-insoluble fraction, $1 \mathrm{mg} \cdot \mathrm{ml}^{-1}$ ). Data was normalized using $\beta$-Tubulin expression. Fold ratio is calculated with the corresponding control sample. Three biological replicates showed consistent results. (b) Fluorometric measures of GUS activities in leaves of transgenic Arabidopsis expressing a PR1::GUS fusion. Plants were infiltrated by water, ulvan (ethanol-insoluble fraction, $1 \mathrm{mg} \cdot \mathrm{ml}^{-1}$ ), or P2 (Phytophthora parasitica cell wall extract, $500 \mu \mathrm{g} \cdot \mathrm{ml}^{-1}$ ). GUS activity was determined 1 day post infiltration and quantified using fluorescent 4-methylumbelliferone as substrate. Mean and standard errors were calculated from three independent replicates. Specific activity is expressed as nkatal per $\mathrm{mg}$ of total proteins. Mean for each treatment was compared to the control mean using a Student's $t$-test. Treatment associated to a $P$-value $\leq .05$ or $\leq .01$ was marked, respectively, by $*$ or $* *$.

and ABA concentration upon ulvan treatment showed that SA concentration was unaffected whereas an increase of JA concentration and a decrease of ABA concentration were observed. Since an antagonist effect between the JA and
ABA pathway has been suggested $[42,43]$, the decrease of free ABA concentration should result in an increase of the JA-dependent response. In contrast, PDF1.2 induction in response to ulvan was impaired on the ABA-mutant suggesting that $\mathrm{ABA}$ was also required to JA-dependent signaling pathway activation. It was recently found that Arabidopsis lines mutated in ABA synthesis genes are impaired in JA accumulation upon bacterial infection, suggesting that ABA can promote JA signaling pathway [44].

Ulvan is a unique polysaccharide found exclusively in green algae, raising the question of its recognition and perception by plant cell. In human and murine cells, ulvan induces the expression of several chemokine and interleukin genes [45]. Such a biological activity has been correlated to structural homologies between ulvan and glycosaminoglycans (GAGs) as they both contain sulfated sugars. GAGs, such as chondroitin sulfate have been reported to be inflammatory mediators activating monocytes [46]. In plants, ulvan might mimic the structure of elicitors containing rhamnose and/or uronic acid residues. Rhamnose is present in plant polysaccharides, such as the rhamnogalacturonan I domain of pectic polysaccharide [47] and in phytopathogenic bacterial rhamnolipids initially identified in Pseudomonas aeruginosa. These two rhamnose-containing compounds trigger defense responses [48, 49]. However, molecular mechanisms underlying their perception remain to be determined.

In conclusion, this study provides a thorough analysis of the elicitor activity of an Ulva spp. extract. We identified the active molecules of the extract as ulvan, a typical polysaccharide of green algae with potential biotechnological applications. Ulvan could be efficient against necrotrophic pathogens because it activates JA signaling pathway which has been shown to be involved against this type of microorganisms [50]. We have previously reported the efficiency of a crude Ulva extract against the hemibiotrophic fungus Colletotrichum trifolii infecting M. truncatula [14]. Accordingly, Ulva extract has also been found to protect Malus domestica from C. gloeosporioides infection [51]. More importantly, greenhouse trials, recently, conducted with artificial inoculation of melon crops with the powdery mildew pathogen Erysiphe cichoracearum, revealed a clear protection conferred by ulvan (Jaulneau et al., unpublished observations). Further work will aim at dissecting more precisely the molecular mechanisms underlying the perception of ulvan in order to optimize its potential use as plant protectant.

\section{Acknowledgments}

This research was supported by "Groupe Roullier" and by a grant of "ANRT". The authors thank Dr. J.M. Prosperi for supplying seeds of Medicago truncatula line F83005.5. They are grateful to the "Genopole Toulouse Midi-Pyrénées" for access to the "Genotyping and Sequencing" and "Biochips" platforms. They also thank Christian Mazars, Gisèle Borderies and Jérôme Bouscault (UMR 5546) for helpful discussions. 


\section{References}

[1] D. Mackey and A. J. McFall, "MAMPs and MIMPs: proposed classifications for inducers of innate immunity," Molecular Microbiology, vol. 61, no. 6, pp. 1365-1371, 2006.

[2] C. Zipfel, "Pattern-recognition receptors in plant innate immunity," Current Opinion in Immunology, vol. 20, no. 1, pp. 10-16, 2008.

[3] D. Lecourieux, C. Mazars, N. Pauly, R. Ranjeva, and A. Pugin, "Analysis and effects of cytosolic free calcium increases in response to elicitors in Nicotiana plumbaginifolia cells," Plant Cell, vol. 14, no. 10, pp. 2627-2641, 2002.

[4] T. Asai, G. Tena, J. Plotnikova, et al., "Map kinase signalling cascade in arabidopsis innate immunity," Nature, vol. 415, no. 6875, pp. 977-983, 2002.

[5] M. R. Grant and J. D. G. Jones, "Hormone (dis)harmony moulds plant health and disease," Science, vol. 324, no. 5928, pp. 750-752, 2009.

[6] N. Shibuya and E. Minami, "Oligosaccharide signalling for defence responses in plant," Physiological and Molecular Plant Pathology, vol. 59, no. 5, pp. 223-233, 2001.

[7] S. Trouvelot, A. L. Varnier, M. Allegre, et al., "A $\beta-1,3$ glucan sulfate induces resistance in grapevine against Plasmopara viticola through priming of defense responses, including HRlike cell death," Molecular Plant-Microbe Interactions, vol. 21, no. 2, pp. 232-243, 2008.

[8] R. Ménard, S. Alban, P. de Ruffray, et al., “ $\beta-1,3$ glucan sulfate, but not $\beta-1,3$ glucan, induces the salicylic acid signaling pathway in Tobacco and Arabidopsis," Plant Cell, vol. 16, no. 11, pp. 3020-3032, 2004.

[9] O. Klarzynski, V. Descamps, B. Plesse, J. C. Yvin, B. Kloareg, and B. Fritig, "Sulfated fucan oligosaccharides elicit defense responses in tobacco and local and systemic resistance against tobacco mosaic virus," Molecular Plant-Microbe Interactions, vol. 16, no. 2, pp. 115-122, 2003.

[10] L. Mercier, C. Lafitte, G. Borderies, X. Briand, M. T. Esquerré-Tugayé, and J. Fournier, "The algal polysaccharide carrageenans can act as an elicitor of plant defence," New Phytologist, vol. 149, no. 1, pp. 43-51, 2001.

[11] D. Lecourieux, O. Lamotte, S. Bourque, et al., "Proteinaceous and oligosaccharidic elicitors induce different calcium signatures in the nucleus of tobacco cells," Cell Calcium, vol. 38, no. 6, pp. 527-538, 2005.

[12] O. Klarzynski, B. Plesse, J. M. Joubert, et al., "Linear $\beta-1,3$ glucans are elicitors of defense responses in tobacco," Plant Physiology, vol. 124, no. 3, pp. 1027-1037, 2000.

[13] R. Ménard, P. de Ruffray, B. Fritig, J. C. Yvin, and S. Kauffmann, "Defense and resistance-inducing activities in tobacco of the sulfated $\beta-1,3$ glucan PS3 and its synergistic activities with the unsulfated molecule," Plant and Cell Physiology, vol. 46, no. 12, pp. 1964-1972, 2005.

[14] S. Cluzet, C. Torregrosa, C. Jacquet, et al., "Gene expression profiling and protection of Medicago truncatula against a fungal infection in response to an elicitor from green algae Ulva spp.," Plant, Cell and Environment, vol. 27, no. 7, pp. 917928,2004

[15] P. Morand and X. Briand, "Excessive growth of macroalgae: a symptom of environmental disturbance," Botanica Marina, vol. 39, no. 6, pp. 491-516, 1996.

[16] M. Lahaye and A. Robic, "Structure and function properties of ulvan, a polysaccharide from green seaweeds," Biomacromolecules, vol. 8, no. 6, pp. 1765-1774, 2007.
[17] A. D. Shapiro and C. Zhang, "The role of NDR1 in avirulence gene-directed signaling and control of programmed cell death in Arabidopsis," Plant Physiology, vol. 127, no. 3, pp. 10891101, 2001.

[18] N. Blumenkrantz and G. Asboe Hansen, "New method for quantitative determination of uronic acids," Analytical Biochemistry, vol. 54, no. 2, pp. 484-489, 1973.

[19] C. Roux, D. Mazau, M. Rickauer, J. Fournier, E. Berthalon, and M. T. Esquerré-Tugayé, "Hydroxyproline-containing fragments in the cell wall of Phytophthora parasitica," Phytochemistry, vol. 35, no. 3, pp. 591-595, 1994.

[20] R. A. Jefferson, T. A. Kavanagh, and M. W. Bevan, "GUS fusions: $\beta$-glucuronidase as a sensitive and versatile gene fusion marker in higher plants," The EMBO Journal, vol. 6, no. 13, pp. 3901-3907, 1987.

[21] S. Forcat, M. H. Bennett, J. W. Mansfield, and M. R. Grant, "A rapid and robust method for simultaneously measuring changes in the phytohormones ABA, JA and SA in plants following biotic and abiotic stress," Plant Methods, vol. 4, no. 1, pp. 1-8, 2008.

[22] M. Kunitz, "The kinetics and thermodynamics of reversible denaturation of crystalline soybean trypsin inhibitor," Journal of General Physiology, vol. 32, no. 2, pp. 241-263, 1948.

[23] O. H. Lowry, N. J. Rosebrough, A. L. Farr, and R. J. Randall, "Protein measurement with the folin phenol reagent," The Journal of Biological Chemistry, vol. 193, no. 1, pp. 265-275, 1951.

[24] A. Fammartino, B. Verdaguer, J. Fournier, et al., "Coordinated transcriptional regulation of the divinyl ether biosynthetic genes in tobacco by signal molecules related to defense," Plant Physiology and Biochemistry, vol. 48, no. 4, pp. 225-231, 2010.

[25] C. Veronesi, M. Rickauer, J. Fournier, M. L. Pouenat, and M. T. Esquerré-Tugayé, "Lipoxygenase gene expression in the tobacco-Phytophthora parasitica nicotianae interaction," Plant Physiology, vol. 112, no. 3, pp. 997-1004, 1996.

[26] R. Thompson, P. Ratet, and H. Küster, "Identification of gene functions by applying TILLING and insertional mutagenesis strategies on microarray-based expression data," Grain Legumes, vol. 41, pp. 20-22, 2005.

[27] A. Devoto and J. G. Turner, "Regulation of jasmonatemediated plant responses in arabidopsis," Annals of Botany, vol. 92, no. 3, pp. 329-337, 2003.

[28] S. H. An, K. H. Sohn, H. W. Choi, I. S. Hwang, S. C. Lee, and B. K. Hwang, "Pepper pectin methylesterase inhibitor protein CaPMEI1 is required for antifungal activity, basal disease resistance and abiotic stress tolerance," Planta, vol. 228, no. 1, pp. 61-78, 2008.

[29] L. Almagro, L. V. Gómez Ros, S. Belchi-Navarro, R. Bru, A. Ros Barceló, and M. A. Pedreño, "Class III peroxidases in plant defence reactions," Journal of Experimental Botany, vol. 60, no. 2, pp. 377-390, 2009.

[30] J. K. Hong, H. W. Choi, I. S. Hwang, et al., "Function of a novel GDSL-type pepper lipase gene, CaGLIP1, in disease susceptibility and abiotic stress tolerance," Planta, vol. 227, no. 3, pp. 539-558, 2008.

[31] C. Bolle, "The role of GRAS proteins in plant signal transduction and development," Planta, vol. 218, no. 5, pp. 683-692, 2004.

[32] L. Navarro, R. Bari, P. Achard, et al., "DELLAs control plant immune responses by modulating the balance of jasmonic acid and salicylic acid signaling," Current Biology, vol. 18, no. 9, pp. 650-655, 2008. 
[33] R. B. Day, S. Tanabe, M. Koshioka, et al., "Two rice GRAS family genes responsive to $\mathrm{N}$-acetylchitooligosaccharide elicitor are induced by phytoactive gibberellins: evidence for cross-talk between elicitor and gibberellin signaling in rice cells," Plant Molecular Biology, vol. 54, no. 2, pp. 261-272, 2004.

[34] C. A. Ryan, "The systemin signaling pathway: differential activation of plant defensive genes," Biochimica et Biophysica Acta, vol. 1477, no. 1-2, pp. 112-121, 2000.

[35] A. Robic, J. F. Sassi, and M. Lahaye, "Impact of stabilization treatments of the green seaweed Ulva rotundata (Chlorophyta) on the extraction yield, the physico-chemical and rheological properties of ulvan," Carbohydrate Polymers, vol. 74, no. 3, pp. 344-352, 2008.

[36] A. Robic, C. Gaillard, J. F. Sassi, Y. Leral, and M. Lahaye, "Ultrastructure of ulvan: a polysaccharide from green seaweeds," Biopolymers, vol. 91, no. 8, pp. 652-664, 2009.

[37] M. Lahaye, E. A. C. Cimadevilla, R. Kuhlenkamp, B. Quemener, V. Lognone, and P. Dion, "Chemical composition and ${ }^{13} \mathrm{C}$ NMR spectroscopic characterisation of ulvans from Ulva (Ulvales, Chlorophyta)," Journal of Applied Phycology, vol. 11, no. 1, pp. 1-7, 1999.

[38] B. Quemener, M. Lahaye, and C. Bobin-Dubigeon, "Sugar determination in ulvans by a chemical-enzymatic method coupled to high performance anion exchange chromatography," Journal of Applied Phycology, vol. 9, no. 2, pp. 179-188, 1997.

[39] B. Ray and M. Lahaye, "Cell-wall polysaccharides from the marine green-alga Ulva-Rigida (Ulvales, Chlorophyta) chemical-structure of ulvan," Carbohydrate Research, vol. 274, pp. 313-318, 1995.

[40] I. A. Penninckx, K. Eggermont, F. R. Terras, et al., "Pathogeninduced systemic activation of a plant defensin gene in Arabidopsis follows a salicylic acid-independent pathway," Plant Cell, vol. 8, no. 12, pp. 2309-2323, 1996.

[41] A. Fammartino, F. Cardinale, C. Gobel, et al., "Characterization of a divinyl ether biosynthetic pathway specifically associated with pathogenesis in tobacco," Plant Physiology, vol. 143, no. 1, pp. 378-388, 2007.

[42] J. P. Anderson, E. Badruzsaufari, P. M. Schenk, et al., "Antagonistic interaction between abscisic acid and jasmonateethylene signaling pathways modulates defense gene expression and disease resistance in Arabidopsis," Plant Cell, vol. 16, no. 12, pp. 3460-3479, 2004.

[43] B. A. Adie, J. Perez-Perez, M. M. Perez-Perez, et al., "ABA is an essential signal for plant resistance to pathogens affecting JA biosynthesis and the activation of defenses in arabidopsis," Plant Cell, vol. 19, no. 5, pp. 1665-1681, 2007.

[44] J. Fan, L. Hill, C. Crooks, P. Doerner, and C. Lamb, "Abscisic acid has a key role in modulating diverse plant-pathogen interactions," Plant Physiology, vol. 150, no. 4, pp. 1750-1761, 2009.

[45] J. M. Leiro, R. Castro, J. A. Arranz, and J. Lamas, "Immunomodulating activities of acidic sulphated polysaccharides obtained from the seaweed Ulva rigida C. Agardh," International Immunopharmacology, vol. 7, no. 7, pp. 879-888, 2007.

[46] J. Rachmilewitz and M. L. Tykocinski, "Differential effects of chondroitin sulfates A and B on monocyte and Bcell activation: evidence for B-cell activation via a CD44dependent pathway," Blood, vol. 92, no. 1, pp. 223-229, 1998.

[47] M. McNeil, A. G. Darvill, and P. Albersheim, "Structure of Plant Cell Walls: X. [rhamnogalacturonan I, a structurally complex pectic polysaccharide in the walls of suspensioncultured sycamore cells," Plant Physiology, vol. 66, no. 6, pp. 1128-1134, 1980.

[48] M. T. Esquerré-Tugayé, G. Boudart, and B. Dumas, "Cell wall degrading enzymes, inhibitory proteins, and oligosaccharides participate in the molecular dialogue between plants and pathogens," Plant Physiology and Biochemistry, vol. 38, no. 1-2, pp. 157-163, 2000.

[49] A. L. Varnier, L. Sanchez, P. Vatsa, et al., "Bacterial rhamnolipids are novel MAMPs conferring resistance to Botrytis cinerea in grapevine," Plant, Cell and Environment, vol. 32, no. 2, pp. 178-193, 2009.

[50] G. J. Beckers and S. H. Spoel, "Fine-tuning plant defence signalling: salicylate versus jasmonate," Plant Biology, vol. 8, no. 1, pp. 1-10, 2006.

[51] L. Araújo, M. J. Stadnik, L. C. Borsato, and R. M. ValdebenitoSanhueza, "Fosfito de potássio e ulvana no controle da mancha foliar da gala em macieira," Tropical Plant Pathology, vol. 33, no. 2, pp. 148-152, 2008. 

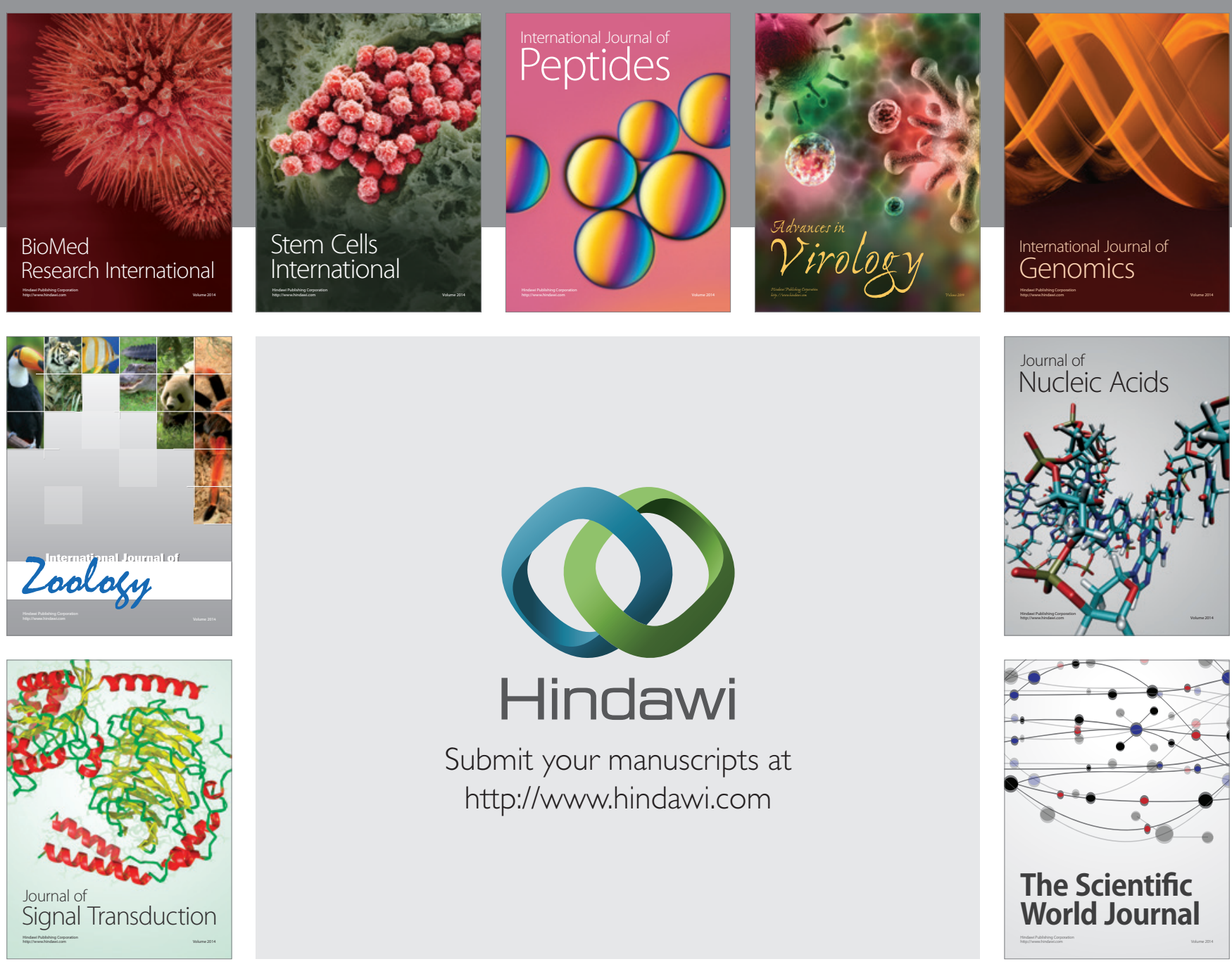

Submit your manuscripts at

http://www.hindawi.com
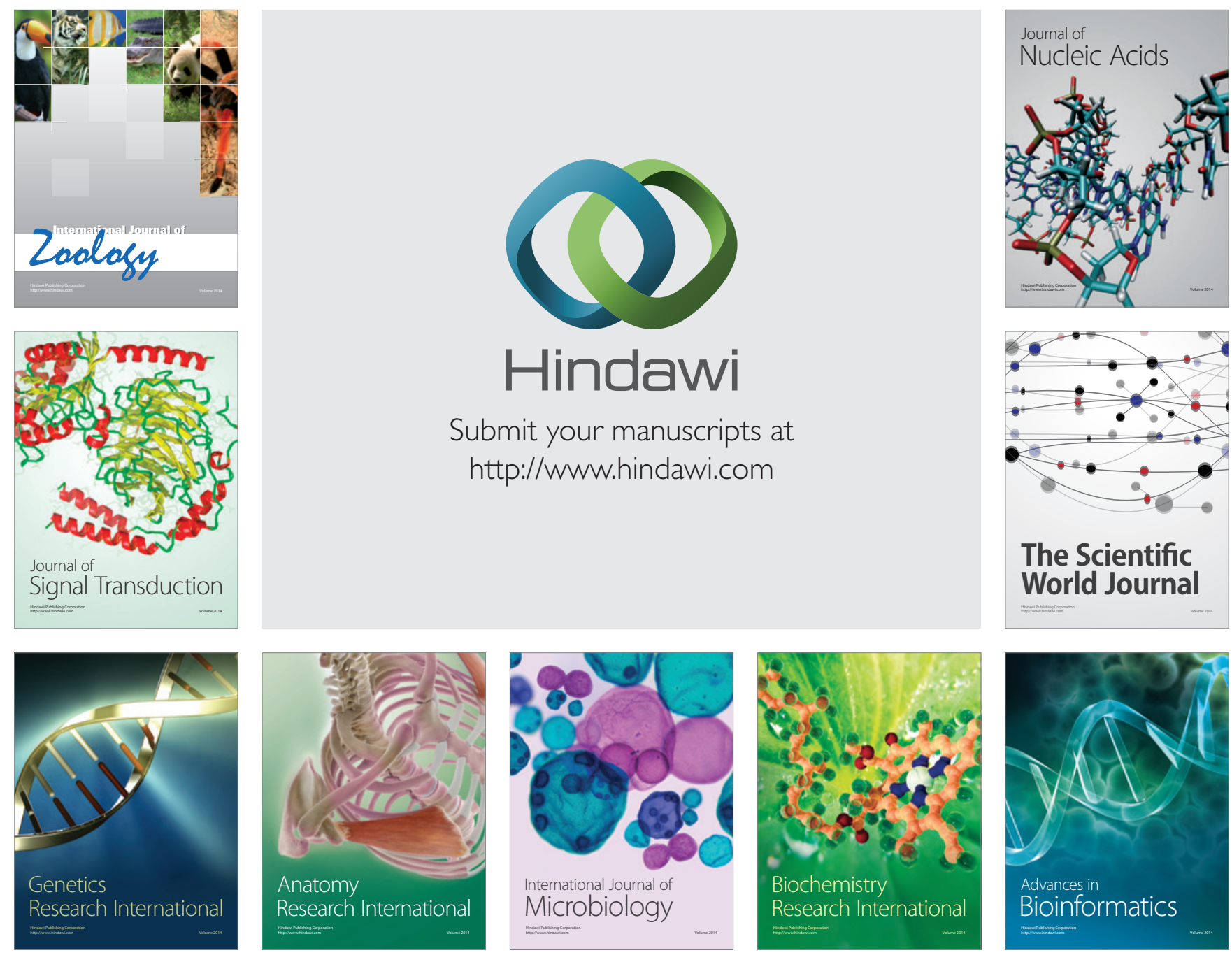

The Scientific World Journal
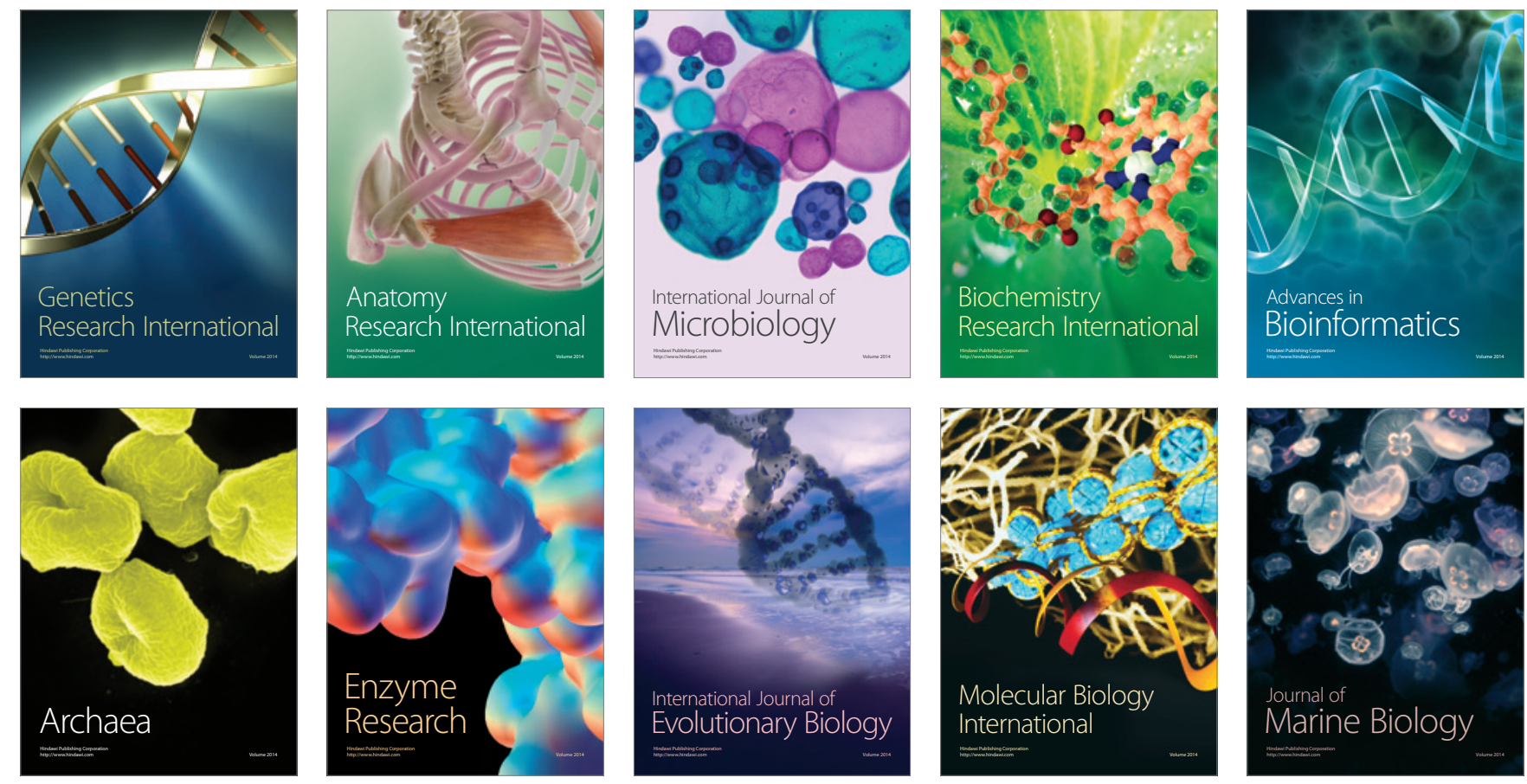